\title{
Pseudomonas putida CE2010 can degrade biphenyl by a mosaic pathway encoded by the tod operon and cmtE, which are identical to those of $P$. putida $F 1$ except for a single base difference in the operator-promoter region of the cmt operon
}

\author{
Yoshinori Ohta, Michihisa Maeda and Toshiaki Kudo
}

Author for correspondence: Toshiaki Kudo. Tel: + 81484679544 . Fax: +81484624672.
e-mail: tkudo@postman.riken.go.jp

Laboratory of

Microbiology, RIKEN (The Institute of Physical and Chemical Research), Hirosawa 2-1, Wako Saitama 351-0198, Japan

\begin{abstract}
Psudomonas putida CE2010 can assimilate biphenyl despite its high similarity to $P$. putida F1. Biphenyl degradation in strain CE2010 was achieved using a mosaic of pathways consisting of the $\mathrm{cmt}$ and tod operons. CmtE hydrolysed 2hydroxy-6-oxo-6-phenylhexa-2,4-dienoic acid, the meta-cleavage product of 2,3dihydroxybiphenyl. This enzyme was expressed differently in strains CE2010 and F1. A cmtE disruption mutant, a tod operon disruption mutant and a cmt operon disruption mutant were unable to utilize biphenyl. The introduction of the cmtE gene enabled the cmt operon disruption mutant to grow on biphenyl. A single base difference was found in the $\mathrm{cmt}$ promoter-operator region in strain CE2010, compared with that of strain F1. CymR protein was purified from Escherichia coli and binding assays were performed, the results of which suggested that the protein bound less strongly to the CE2010 operator sequence than to the F1 operator sequence. Exchanging the F1 promoter-operator fragment into strain CE2010 resulted in a loss of biphenyl degradation capacity. These results indicate that $\mathrm{cmtE}$ is not effectively repressed by CymR in strain CE2010, leading to low constitutive expression and, therefore, low growth on biphenyl.
\end{abstract}

Keywords: biphenyl, mosaic pathway, biodegradation, Pseudomonas putida

\section{INTRODUCTION}

Aromatic hydrocarbon-degrading bacteria are widely distributed in nature and have acquired various kinds of metabolic pathways through the course of evolution. Biphenyl-degrading bacteria have been isolated from the environment. The major catabolic pathway is the most common pathway for biphenyl degradation (Catelani et al., 1973; Hayase et al., 1990; Kimbara et al., 1989; see Fig. 2).

Abbreviations: 2,3-DHBP, 2,3-dihydroxybiphenyl; 2,3-DHBD, 2,3dihydroxybiphenyl dioxygenase; HPDA, 2-hydroxy-6-oxo-6-phenylhexa2,4-dienoic acid; HOHD, 2-hydroxy-6-oxo-hepta-2,4-dienoic acid; Ap, ampicillin; $\mathrm{Cb}$, carbenicillin; $\mathrm{Km}$, kanamycin; $\mathrm{Tc}$, tetracycline.

The DDBJ accession numbers for the sequences reported in this paper are AB042508 and AB042509.
Similar reactions are found in different catabolic pathways. The benzene/toluene degrader Pseudomonas putida BE81 has bnz genes (Irie et al., 1987). Pseudomonas sp. mt-2 has a $x y l$ operon encoding the catabolic enzymes required for growth on xylene and toluene (Harayama \& Rekik, 1990). It is postulated that a number of catabolic genes involved in the degradation of aromatic compounds share a common ancestry and form gene superfamilies (Meer et al., 1992).

Catabolic genes in bacteria are often clustered in operons and the comparison of gene organization of catabolic operons among various bacteria has demonstrated that functional clusters of genes often move as units from one genetic element to another (Meer et al., 1992). The order of the genes responsible for the oxidation of benzoate to catechol on the chromosome of Acinetobacter calcoaceticus (ben $A B C D$ ) is the same as that on the TOL 
plasmid of P. putida (xylXYZL) (Harayama et al., 1991). The genetic organization of the meta operons of the TOL and NAH plasmids are very similar, although regulator XylS belongs to the AraC family and NahR belongs to the LysR family (Lorenzo et al., 1996). Gene movements or pathway shuffling are ways for bacteria to expand their substrate specificity and to adapt to the environment.

From the viewpoint of the expansion of substrate specificity as a functional unit, the co-evolution of several enzymes is often necessary because the catabolic pathways consist of multiple enzymic steps. If the range of compounds which might be degraded by the particular functional unit is limited by a single enzyme with narrow substrate specificity, the recruitment of another enzyme is sufficient to expand the substrate range of the pathway. P. putida F1 grows well on toluene/benzene but not on biphenyl (Gibson et al., 1968). Despite the discrete substrate specificity, the $b p h$ and tod operons are very similar, not only in terms of gene organization and pathway, but also in terms of the sizes and the deduced amino acid sequences of the gene products (Zylstra et al., 1988; Lau et al., 1994). The inability of $P$. putida $\mathrm{F} 1$ to grow on biphenyl is due to the lack of TodF activity for biphenyl meta-cleavage of 2-hydroxy-6-oxo6-phenylhexa-2,4-dienoic acid (HPDA) (Furukawa et al., 1993). The introduction of the $b p h D$ gene derived from Pseudomonas pseudoalcaligenes KF707 into $P$. putida F1 permits its growth on biphenyl. It might be one of the strategies of natural evolution that the expansion of substrate specificity and the adaptation to a new substrate are achieved by enzyme recruitment.

Recently, P. putida CE2010 was isolated from refinery wastewater and was found to be capable of degrading PCB/biphenyl in the presence of an organic solvent (Ohta et al., 1996). P. putida CE2010 is very similar to $P$. putida F1, except for its ability to degrade biphenyl. In this study we analysed the mechanisms involved in the biphenyl degradation pathway in strain CE2010. $P$. putida CE2010 degrades biphenyl using a mosaic of pathways consisting of tod and $c m t$ operons. Biphenyl degradation is achieved by the recruitment of $\mathrm{CmtE}$ together with the tod pathway in P. putida CE2010. We found that a single base difference in the operatorpromoter region of the cmt operon, $\mathrm{CmtE}$ and the tod operon are all essential for biphenyl degradation in this strain.

\section{METHODS}

Bacterial strains, plasmids and culture conditions. Biphenylutilizing $P$. putida CE2010 has been described previously (Ohta et al., 1996), as has toluene-utilizing P. putida F1 (Gibson et al., 1968) and this strain was obtained from ATCC (Manassas, VA, USA). P. putida CE2010 was grown on C medium, which contained $\left(1^{-1}\right): 5 \mathrm{~g} \quad\left(\mathrm{NH}_{4}\right)_{2} \mathrm{SO}_{4}, 5 \cdot 87 \mathrm{~g}$ $\mathrm{KH}_{2} \mathrm{PO}_{4}, 0.3 \mathrm{~g} \mathrm{MgSO}_{4} .7 \mathrm{H}_{2} \mathrm{O}, 2 \mathrm{~g} \mathrm{NaCl}, 0.03 \mathrm{~g} \mathrm{CaCl}_{2}, 0.01 \mathrm{~g}$ $\mathrm{FeSO}_{4} .7 \mathrm{H}_{2} \mathrm{O}, 0.6 \mathrm{mg} \mathrm{NiSO} .7 \mathrm{H}_{2} \mathrm{O}, 0.1 \mathrm{~g}$ yeast extract and $2 \mathrm{ml}$ trace elements solution. The trace elements solution contained $\left(1^{-1}\right): 4 \mathrm{mg} \mathrm{MoO}_{3}, 28 \mathrm{mg} \mathrm{ZnSO}_{4} .5 \mathrm{H}_{2} \mathrm{O}, 2 \mathrm{mg}$ $\mathrm{CuSO}_{4} .5 \mathrm{H}_{2} \mathrm{O}, 4 \mathrm{mg} \mathrm{H} \mathrm{BO}_{3}, 4 \mathrm{mg} \mathrm{MnSO}_{4} .5 \mathrm{H}_{2} \mathrm{O}$ and $4 \mathrm{mg}$
$\mathrm{CoCl}_{2} \cdot 6 \mathrm{H}_{2} \mathrm{O}$. Biphenyl was added to $\mathrm{C}$ medium at a final concentration of $0.5 \%$ as sole carbon source and cultures were incubated on a reciprocal shaker at 120 r.p.m. at $30^{\circ} \mathrm{C}$. Escherichia coli JM109 $\{\Delta($ lac-proAB) end 11 gyrA96 hsdR17 $\lambda^{-}$relA1 supE44 thi $\left[\mathrm{F}^{\prime}\right.$ lacl $^{q} \mathrm{Z} \Delta \mathrm{M} 15$ proAB traD36 $\left.]\right\}$ and MV1184 \{ara $, \Delta($ lac-proAB $) \Delta\left(\right.$ stl $^{-}$racA $) 306:: \operatorname{Tn} 10$ $\phi 80 \mathrm{~d} l a c Z \Delta \mathrm{M} 15$ rpsL $L^{-}$thi [F $^{\prime}$ lacl $^{a} \mathrm{Z} \Delta \mathrm{M} 15$ proAB traD36]\} were used as recipient strains for transformation experiments. E. coli JM109 and MV1184 were routinely grown at $37^{\circ} \mathrm{C}$ in Luria-Bertani (LB) broth containing ampicillin (Ap; $\left.50 \mu \mathrm{g} \mathrm{ml}^{-1}\right)$ or IPTG $(500 \mu \mathrm{M})$ when necessary. pUC118 and pUC119 vectors were used to clone the $b p h C$ gene. All recombinant Pseudomonas strains were constructed by triparental mating with E. coli JM109 (as the donor strain which carried one of the recombinant plasmids constructed containing the $c m t_{\mathrm{CE2010}}$ or $c y m_{\mathrm{CE2010}}$ genes) and E. coli HB101A(pRK2013) as a helper strain. The transconjugants were obtained by spreading the mixture on Pseudomonas medium (Difco) with kanamycin $\left(\mathrm{Km} ; 25 \mu \mathrm{g} \mathrm{ml}^{-1}\right)$ or tetracycline $\left(\mathrm{Tc} ; 25 \mu \mathrm{g} \mathrm{ml}^{-1}\right.$ ).

Biphenyl- and toluene-utilizing strains were grown at $30^{\circ} \mathrm{C}$ in $\mathrm{C}$ medium containing biphenyl or toluene as sole carbon source. Antibiotics were added at the following concentrations to select for the presence of the plasmid and the knock-out strains: Ap at $50 \mu \mathrm{g} \mathrm{ml}^{-1}$ for E. coli strains and at $300 \mu \mathrm{g} \mathrm{ml}^{-1}$ for Pseudomonas strains; Tc at $12.5 \mathrm{\mu g} \mathrm{ml}^{-1}$ for E. coli strains and at $25 \mu \mathrm{g} \mathrm{ml}^{-1}$ for Pseudomonas strains; Km at $25 \mu \mathrm{g} \mathrm{ml}^{-1}$ for E. coli and Pseudomonas strains.

Enzyme assays. 2,3-Dihydroxybiphenyl dioxygenase (2,3DHBD) activity was determined by measuring the formation of meta-cleavage reaction products at $434 \mathrm{~nm}$ using a Hitachi model 330 spectrophotometer equipped with a water-cooled cell holder and a Haake circulating water bath. Activity assays were performed at $30^{\circ} \mathrm{C}$ using reaction mixtures containing $200 \mu \mathrm{M} 2,3$-dihydroxybiphenyl (2,3-DHBP) as the substrate in $50 \mathrm{mM}$ Tris $/ \mathrm{HCl}(\mathrm{pH} 7 \cdot 5)$. One unit of enzyme activity was defined as the amount of enzyme that catalysed the formation of $1 \mu \mathrm{mol}$ product $\mathrm{min}^{-1}$ at $30^{\circ} \mathrm{C}$. The molecular extinction coefficient of the product under these assay conditions was taken to be $13200 \mathrm{~cm}^{-1} \mathrm{M}^{-1}$ (Maeda et al., 1995). The relative ring cleavage activities were determined from the extinction coefficient of the ring fission products formed from the following substrates: catechol $\left(\lambda_{\max } 375 \mathrm{~nm} ; \varepsilon\right.$ $36000 \mathrm{~cm}^{-1} \mathrm{M}^{-1}$ ).

HPDA hydrolysis activity (BphD-like activity) was assayed spectrophotometrically by monitoring the decrease in $A_{434}$. Specific activity was defined as the number of enzyme units $(\mathrm{mg} \text { protein })^{-1}$. HPDA was prepared by incubation of recombinant E. coli (carrying the $b p h C$ gene) with 2,3-DHBP immediately before assaying hydrolase activity. Following the incubation period, the cells were removed by centrifugation and the supernatant was filtered using a $40 \mu \mathrm{m}$ pore-size filter (Amicon). The protein concentration was assayed using a protein assay kit (Bio-Rad), according to the method of Bradford (1976).

Purification of an enzyme hydrolysing HPDA. Chromatography was performed on an FPLC system (Amersham Pharmacia Biotech). Wet P. putida CE2010 cells (6.2 g) were suspended in $20 \mathrm{ml} 30 \mathrm{mM}$ Tris/ $\mathrm{HCl}$ buffer, $\mathrm{pH} 7 \cdot 5$ (Buffer A), and disrupted by sonication (Branson TW3). The supernatant fluid was prepared by centrifugation at $28000 \mathrm{~g}$ for $30 \mathrm{~min}$ as a crude extract. To the mixture, $3.5 \mathrm{~g}$ $\left(\mathrm{NH}_{4}\right)_{2} \mathrm{SO}_{4}$ was added, the resulting precipitate was removed by centrifugation at $28000 \mathrm{~g}$ for $20 \mathrm{~min}$ and the supernatant fraction was resuspended in $40 \mathrm{ml}$ Tris $/ \mathrm{HCl}$ buffer, $\mathrm{pH} 7 \cdot 5$, 


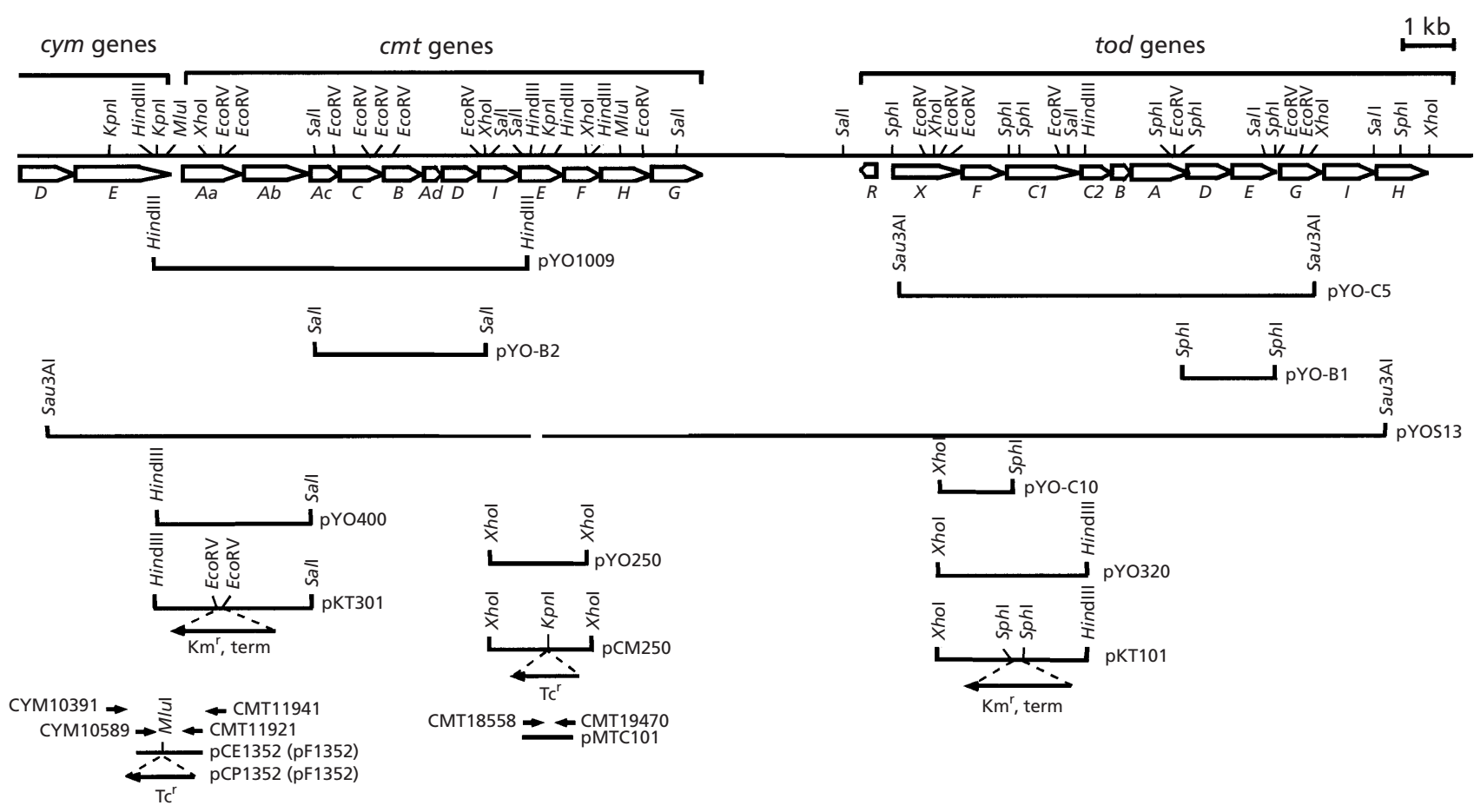

Fig. 1. (a) Cloning and localization of $P$. putida CE2010 gene 1 and gene 2 encoding the enzyme that catalyses ring metacleavage of 2,3-DHBP. The restriction map of the tod operon is from Zylstra \& Gibson (1989) and those of the $\mathrm{cmt}$ operons are from Eaton $(1996,1997)$. The location of the genes encoding $\mathrm{cmt}$ or tod pathway enzymes is indicated at the top. Below the map the DNA fragments cloned and the subclones obtained are shown.

containing $1 \mathrm{M}\left(\mathrm{NH}_{4}\right)_{2} \mathrm{SO}_{4}$. The $\left(\mathrm{NH}_{4}\right)_{2} \mathrm{SO}_{4}$ fraction was applied to a Phenyl Sepharose column $(1.6 \times 15 \mathrm{~cm}$; Amersham Pharmacia Biotech) previously equilibrated with Buffer A containing $1 \mathrm{M}\left(\mathrm{NH}_{4}\right)_{2} \mathrm{SO}_{4}$. The enzyme was eluted with a linear gradient mixture of $200 \mathrm{ml}$ Buffer A containing $1 \mathrm{M}\left(\mathrm{NH}_{4}\right)_{2} \mathrm{SO}_{4}$ and Buffer $\mathrm{A}$ at a flow rate of $1 \mathrm{ml} \mathrm{min}^{-1}$. The active fractions were collected, dialysed against Buffer A and applied to a MonoQ column $(0.5 \times 10 \mathrm{~cm}$; Amersham Pharmacia Biotech) equilibrated with Buffer A. The enzyme was eluted with a linear gradient mixture of $20 \mathrm{ml}$ Buffer A and $20 \mathrm{ml}$ Buffer A containing $0.5 \mathrm{M} \mathrm{NaCl}$ at a flow rate of $0.5 \mathrm{ml} \mathrm{min}$. Eluted fractions were subjected to a $12.5 \%$ SDSPAGE analysis. Molecular mass standard proteins used were bovine serum albumin $\left(M_{\mathrm{r}}\right.$ 66000), ovalbumin (46000), carbonic anhydrase (30000), trypsin inhibitor (21500) and lysozyme (14300).

Gel filtration methods. The native mass of the protein which hydrolyses HPDA was estimated by gel filtration through a Sephacryl S200HR column $(1.6 \times 100 \mathrm{~cm}$; Amersham Pharmacia Biotech; flow rate $15 \mathrm{ml} \mathrm{h}^{-1}$ ) in Buffer A containing $150 \mathrm{mM} \mathrm{NaCl}$. The calibration proteins were albumin $\left(M_{\mathrm{r}}\right.$ $67000)$, ovalbumin (43000), chymotrypsinogen A (25000) and ribonuclease A (13700).

DNA manipulations. Restriction analysis and recombinant DNA techniques were performed by standard methods (Sambrook et al., 1989).

Cloning of the gene that encoding 2,3-DHBD activity. Genomic DNA from P. putida CE2010 and P. putida F1 was prepared by a procedure based on the method described by Wilson (1990). P. putida CE2010 chromosomal DNA was digested partially with Sau3AI or HindIII and DNA fragments were fractionated by agarose gel electrophoresis. The DNA fragments were ligated to pUC118, which had been digested with BamHI or HindIII, or pKS13 which had been digested with BamHI, and treated with alkaline phosphatase. The resulting plasmids were introduced into E. coli JM109 by transformation and the cells were plated on LB agar medium containing Ap and IPTG. The resulting cosmid library was introduced into E. coli VCS257 using the Gigapack II Packaging Extracts Kit (Stratagene) and the cells were plated on LB agar medium containing Tc. Clones that expressed meta-cleavage dioxygenase activity were identified by spraying colonies with a solution containing $20 \mathrm{mM}$ 2,3-DHBP in acetone. Positive clones turned yellow. A $9.5 \mathrm{~kb}$ Sau3A fragment (pYO-C5) and $7 \cdot 4 \mathrm{~kb}$ HindIII fragment (pYO1009) were obtained from the plasmid in the positive clones.

Construction of a $\mathbf{c m t} E_{\mathrm{CE} 2010}$-deficient mutant of strain CE2010. The $c m t E_{\mathrm{CE2010}}$ gene of pYO250 was disrupted by insertion of a blunt-ended $1.4 \mathrm{~kb}$ EcoRI-StyI fragment of pBR322, which carries the Tc resistance gene, into the KpnI site (pCM250) (Fig. 1). The inserted fragment of pCM250 was moved to pKTYMCS (Table 1) and introduced into strain CE2010 by tri-parental mating with pRK2013 as a helper plasmid. All recombinant Pseudomonas strains were constructed by tri-parental mating with E. coli JM109 (as the donor strain carrying one of the recombinant plasmids constructed containing the $c m t_{\mathrm{CE} 2010}$ or $c y m_{\mathrm{CE2010}}$ genes) and E. coli HB101(pRK2013) as a helper strain. The transconjugants were obtained by spreading the mixture on Pseudomonas medium (Difco) with Tc $\left(25 \mu \mathrm{g} \mathrm{ml}^{-1}\right)$. A Tc ${ }^{\mathrm{r}}$ transconjugant was selected from among the transformed cells. Insertion of the $1.4 \mathrm{~kb}$ fragment into the $\mathrm{cmt} \mathrm{E}_{\mathrm{CE} 2010}$ gene on the chromosome was confirmed by Southern blot analysis 
Table 1. Bacterial strains, plasmids and oligonucleotides used in this study

\begin{tabular}{|c|c|c|}
\hline Strain/plasmid & Relevant characteristics & Source/reference \\
\hline \multicolumn{3}{|l|}{ Strain } \\
\hline P. putida CE2010 & Biphenyl/PCB-degrading bacterium & Ohta et al. (1996) \\
\hline P. putida F1 & Toluene-degrading bacterium & Gibson et al. (1968) \\
\hline E. coli JM109 & Host strain for DNA manipulation & Toyobo \\
\hline \multicolumn{3}{|l|}{ Plasmids } \\
\hline pUC118 & Cloning vector; $A \mathrm{p}^{\mathrm{r}}$ & Toyobo \\
\hline KS + Bluescript & Cloning vector; $\mathrm{Ap}^{\mathrm{r}}$ & Toyobo \\
\hline pBR322 & Cloning vector; $\mathrm{Ap}^{\mathrm{r}}, \mathrm{Tc}^{\mathrm{r}}$ & Toyobo \\
\hline pMW218 & Cloning vector; $\mathrm{Km}^{\mathrm{r}}$ & Nippon Gene \\
\hline pKK233-3 & Expression vector; $A p^{r}$ & Pharmacia-Amersham \\
\hline pGEX-4T-1 & GST gene fusion vector & Pharmacia-Amersham \\
\hline pMMB67EH & IncQ, tac promoter; $\mathrm{Ap}^{\mathrm{r}}, \mathrm{Cb}^{\mathrm{r}}$ & Fürste et al. (1986) \\
\hline pRK2013 & Helper plasmid & Fürste et al. (1986) \\
\hline pKS13 & Broad-host-range cosmid vector & Kimbara et al. (1989) \\
\hline pTER3400 & $\begin{array}{l}1.2 \mathrm{~kb} \mathrm{Km}^{\mathrm{r}} \text { gene from pMW } 218 \text { and } 0.9 \mathrm{~kb} \mathrm{rrnB} \text { terminator gene from } \\
\text { pKK233-3 inserted into HincII-digested pUC118 }\end{array}$ & This study \\
\hline pKTY320:: Tn5 & Suicide vector & Nagata et al. (1993) \\
\hline pKTY $\Delta \mathrm{EH}$ & pKTY320:: Tn5 digested with EcoRI and HindIII, blunt-ended and re-ligated & This study \\
\hline pKTYMCS & $\begin{array}{l}0 \cdot 2 \mathrm{~kb} \text { PvuII fragment (containing multi-cloning sites) from Bluescript SK+ } \\
\text { inserted into PvuII-digested pKTY } \mathrm{EH}\end{array}$ & This study \\
\hline pMTC67EH & $\begin{array}{l}1.4 \mathrm{~kb} \text { fragment from pBR322 }\left(\mathrm{Tc}^{\mathrm{r}}\right) \text { inserted into HindIII site of } \mathrm{pMMB} 67 \mathrm{EH} \text {; } \\
\mathrm{Ap}^{\mathrm{r}}, \mathrm{Tc}^{\mathrm{r}}\end{array}$ & This study \\
\hline pYO-C5 & $9 \cdot 5 \mathrm{~kb}$ Sau3AI fragment from $P$. putida CE2010 inserted into pUC118 & This study \\
\hline pYO1009 & $7 \cdot 4 \mathrm{~kb}$ HindIII fragment from P. putida CE2010 inserted into pUC118 & This study \\
\hline pYOS13 & $27 \mathrm{~kb}$ Sau3AI fragment from $P$. putida CE2010 inserted into pKS13 & This study \\
\hline pYO-B1 & $2 \cdot 0 \mathrm{~kb} S p h \mathrm{I}$ fragment from pYO-C5 inserted into $S p h \mathrm{I}$-digested pUC118 & This study \\
\hline pYO-C10 & $\begin{array}{l}1.6 \mathrm{~kb} \text { XhoI and SphI fragment from pYO-C5 inserted into HincII-digested } \\
\text { pUC118 }\end{array}$ & This study \\
\hline pYO320 & $\begin{array}{l}3 \cdot 0 \mathrm{~kb} \text { XhoI-HindIll fragment from pYO-C5 inserted into XhoI/HindIll- } \\
\text { digested Bluescript KS + }\end{array}$ & This study \\
\hline pKT101 & $\begin{array}{l}2.1 \mathrm{~kb} \text { fragment containing a } \mathrm{Km}^{\mathrm{r}} \text { gene and a } \mathrm{rrnB} \text { terminator gene from } \\
\text { pTER3400 inserted into } S p h \mathrm{I} \text {-digested and blunt-ended pYO320 }\end{array}$ & This study \\
\hline pYO-B2 & $3 \cdot 4 \mathrm{~kb}$ SalI fragment from pYO1009 inserted into SalI-digested pUC118 & This study \\
\hline pYO250 & $2 \cdot 0 \mathrm{~kb}$ Xhol fragment from pYOS13 inserted into Hincll-digested pUC118 & This study \\
\hline pCM250 & 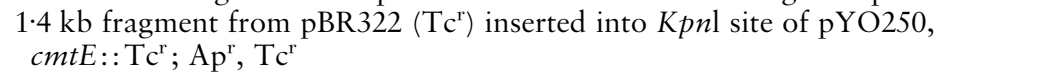 & This study \\
\hline pYO400 & pYO1009 digested with SalI and re-ligated $(3 \cdot 3 \mathrm{~kb}) ; \mathrm{Ap}^{\mathrm{r}}$ & This study \\
\hline pKT301 & $\begin{array}{l}2 \cdot 1 \mathrm{~kb} \text { fragment containing a } \mathrm{Km}^{\mathrm{r}} \text { gene and a } \mathrm{rrnB} \text { terminator gene from } \\
\text { pTER3400 inserted into EcoRV-digested pYO400 }\end{array}$ & This study \\
\hline pMTC101 & $0.9 \mathrm{~kb}$ PCR fragment carrying $c m t E$ in pMTC67EH cloning vector; $\mathrm{Ap}^{\mathrm{r}}, \mathrm{Tc}^{\mathrm{r}}$ & This study \\
\hline pCE1352 & $\begin{array}{l}1.5 \mathrm{~kb} \text { PCR fragment carrying a part of } c y m E, \mathrm{cmt} \text { promoter region and a part } \\
\text { of } c m t \text { t } 1 \text { from } P \text {. putida CE2010 in Bluescript KS }+\end{array}$ & This study \\
\hline pF1352 & $\begin{array}{l}1.5 \mathrm{~kb} \text { PCR fragment carrying a part of } c y m E, \mathrm{cmt} \text { promoter region and a part } \\
\text { of } c m t A 1 \text { from } P \text {. putida } \mathrm{F} 1 \text { in Bluescript } \mathrm{KS}+\end{array}$ & This study \\
\hline pCP1352 & $1.4 \mathrm{~kb}$ fragment from pBR322 $\left(\mathrm{Tc}^{\mathrm{r}}\right)$ inserted into $M l u l$ site of pCE1352 & This study \\
\hline pFP1352 & $1.4 \mathrm{~kb}$ fragment from pBR322 $\left(\mathrm{Tc}^{\mathrm{r}}\right)$ inserted into $M l u l$ site of $\mathrm{pFl} 352$ & This study \\
\hline pGSTcymR & $0 \cdot 6 \mathrm{~kb}$ PCR fragment carrying $c y m R$ in pGEX-4T-1; $\mathrm{Ap}^{\mathrm{r}}$ & This study \\
\hline \multicolumn{3}{|l|}{ Oligonucleotide } \\
\hline CEPro & AGGCCCTAGCAACTTGACAGGTGAATTCGAGGCGGATGA & \\
\hline & TTTTTTTTGAAAACAAACACACAATCTGGTCAGTTTGTA & \\
\hline & TTATAAGTAAAAACACCCACGT & \\
\hline F1Pro & AGGCCCTAGCAACTTGACAGGTGAATTCGAGGCGGATGA & \\
\hline & TTTTTTTTGAAAACAAACACACAATCTGGTCTGTTTGTA & \\
\hline & TTATAAGTAAAAACACCCACGT & \\
\hline \multicolumn{3}{|l|}{ PCR primer } \\
\hline CYM10589 & CTTCGTTGTTGTATGAGGGCTTGC & \\
\hline CYM10391 & ACCTGCTTTACACATCGGGCAC & \\
\hline CMT11921 & ATACGGCAAGTGGCTCTCCTCT & \\
\hline CUT11941 & TTGGATAGCTGCGGCCTTTCAT & \\
\hline CMT18558 & GAATTCTATAGAGAGGTATTTATG & \\
\hline CMT19470 & GAATTCACAGGTTCGCAATCACGTT & \\
\hline CYMRN & GAATTCATGAGTCCAAAGAGAAGAACACAGGCAGA & \\
\hline CYMRC & GAATTCCTAGCGCTTGAATTTCGCGTACCGCTCT & \\
\hline
\end{tabular}


(Southern, 1975; Anderson \& Young, 1985) using a 2.0 kb Xhol fragment from pYO250 as probe. To confirm double crossover mutants, the insertion mutants were streaked on LB plates containing Ap $\left(300 \mu \mathrm{g} \mathrm{ml}^{-1}\right)$ (Wang et al., 1995). Wildtype $P$. putida CE2010 was tolerant to Ap $\left(100 \mu \mathrm{g} \mathrm{ml}^{-1}\right)$. The single crossover mutants grew well on the plates, since they were derived from the integration of the whole plasmid (containing the Ap resistance gene from pKTYMCS) into the P. putida CE2010 chromosome. But the double crossover mutants did not grow or grew slowly on the plates. These phenotypes showed the correlation with their crossover type through the insertion mutants.

Construction of tod $_{\mathrm{CE2010}}$-operon-deficient and $\mathrm{cmt}_{\mathrm{CE2010}}$ operon-deficient mutants of strain CE2010. pYO320 carried partial tod $X_{\mathrm{CE2010}}$, tod $F_{\mathrm{CE} 2010}$ and todC1 $1_{\mathrm{CE} 2010}$ genes and pYO400 carried $c m t A a_{\mathrm{CE2010}}$ and $c m t A b_{\mathrm{CE2010}}$ (Fig. 1). A blunt-ended $2 \cdot 1 \mathrm{~kb} E c o \mathrm{RI}$ and PvuI fragment of pTER3400, which carried a $\mathrm{Km}^{\mathrm{r}}$ gene and an $\mathrm{rrnB}$ terminator gene, was inserted into the SphI site of pYO320 (pKT101), or into the EcoRV site of pYO400 (pKT301). The inserted fragment was moved to pKTYMCS. The inserted fragments were introduced into strain CE2010 as described above. A $\mathrm{Km}^{\mathrm{r}}$ strain was selected from among the transformed cells. Insertion of the $\mathrm{Km}^{\mathrm{r}}$ gene and the $\mathrm{rrnB}$ terminator gene into the todC1 $1_{\mathrm{CE2010}}$ gene or the $c m t A a_{\mathrm{CE2010}}$ gene on the chromosome was confirmed by Southern blot analysis using a $2.0 \mathrm{~kb} E c o R V$ fragment from pYO320 or a $2.0 \mathrm{~kb}$ EcoRI fragment from pYO400, respectively, as a probe. Double crossover mutation was confirmed as described above.

Cloning of the $c m t E_{\mathrm{CE} 2010}$ gene into a broad-host-range vector. A $0.9 \mathrm{~kb}$ fragment containing the $c m t E_{\mathrm{CE} 2010}$ gene was amplified from strain CE2010 DNA by PCR using CMT18558 and CMT19470 as primers. pMTC101 was constructed by insertion of the amplified fragment into the EcoRI site of the cloning vector pMTC67EH (Fig. 1). Strains CE2010 and F1 were transformed with pMTC67EH and pMTC101 by triparental mating with pRK2013 as a helper plasmid.

Replacement of the $\mathrm{cmt}$ promoter region. A $1.5 \mathrm{~kb}$ fragment containing a part of $c y m E$, the $c m t$ promoter region and a part of $c m t A 1$ was amplified from the DNA of strain CE2010 or strain F1 by PCR with CYM10589 and CMT11921 as primers (Table 1 and Fig. 1). The PCR fragment was inserted into the SmaI site of Bluescript KS + after being blunt-ended with Klenow fragment (pCE1352 and pF1352). A blunt-ended $1.4 \mathrm{~kb}$ fragment which carried the Tc resistance gene was inserted into the MluI site of pCE1352 and pF1352 in the direction opposite to that of the $c m t$ promoter (pCP1352, pFP1352; Fig. 1). The inserted fragment was moved to pKTYMCS and introduced into strain CE2010 and strain F1 as described above. $\mathrm{Tc}^{\mathrm{r}}$ strains were selected from among the transformed cells. Insertion of a $2.9 \mathrm{~kb}$ fragment into the $c m t$ promoter region on the chromosome of each strain was confirmed by Southern blot analysis using a $1.5 \mathrm{~kb}$ fragment from pCE1352 as a probe. Double crossover mutation was confirmed as described above. The replaced $\mathrm{cmt}$ promoter region was amplified from recombinant strain CE2010 and strain F1 by PCR with CYM10391 and CMT11941 as primers. The PCR fragment was subcloned into the SmaI site of Bluescript KS + after being blunt-ended and the nucleotide sequence was confirmed by the dideoxy sequencing method.

Overexpression of CymR and DNA binding. CymR was overproduced as a fusion protein using a commercial glutathione $S$-transferase (GST) system. A 620 bp fragment containing $c y m R$ was amplified from strain CE2010 by PCR with CYMRN and CYMRC as the primers and inserted into
pGEX-4T-1 (Pharmacia Amersham) at the EcoRI site. The resulting plasmid, encoding the CymR fusion to GST, was designated pGSTcymR. A $50 \mathrm{kDa}$ fusion protein was produced in E. coli JM109 cells induced with $1 \mathrm{mM}$ IPTG for $4 \mathrm{~h}$. The fusion protein was purified according to the manufacturer's instructions.

The DNA binding assay was carried out as follows. Two $100 \mathrm{bp}$ fragments of double-stranded DNA, one containing the $c m t$ promoter region of $P$. putida CE2010 (CEPro; Table 1 ) and the other containing that of $P$. putida F1 (F1Pro), were synthesized as probes and labelled at one end with digoxigenin (Boehringer Mannheim). Assay mixtures containing $1 \mu \mathrm{g}$ CymR and varying amounts of labelled DNA $(40 \mathrm{fmol}$, $200 \mathrm{fmol}$ ) in $20 \mu \mathrm{l}$ binding buffer ( $20 \mathrm{mM}$ HEPES, $\mathrm{pH} 7 \cdot 6$, $1 \mathrm{mM}$ EDTA, $10 \mathrm{mM}\left(\mathrm{NH}_{4}\right)_{2} \mathrm{SO}_{4}, 1 \mathrm{mM}$ DTT, $0 \cdot 2 \%$, w/v, Tween 20, $30 \mathrm{mM} \mathrm{KCl}, 1 \mu \mathrm{g}$ Poly[d(I-C)], 1 ng poly-L-lysine) were incubated on ice for $20 \mathrm{~min}$. The samples were separated by electrophoresis in a $6 \%$ polyacrylamide gel containing $0.2 \times$ TBE $(89 \mathrm{mM}$ Tris $/ \mathrm{HCl}, \mathrm{pH} 8.0,89 \mathrm{mM}$ boric acid, $2 \mathrm{mM}$ EDTA). The probe DNA was transferred to a Hybond$\mathrm{N}$ membrane (Amersham). Detection of the digoxigeninlabelled probe was carried out by means of the chemiluminescence detection system using the Boehringer Mannheim kit according to the instruction manual. Imaging of the chemiluminescence was performed using Fuji RX film by exposure for $1 \mathrm{~h}$.

\section{RESULTS}

\section{Screening of the library for meta-cleavage dioxygenase expression and identification of the clones}

A gene (gene 1) encoding an enzyme that catalyses ring meta-cleavage of 2,3-DHBP was subcloned from pYOC5 as a $2.0 \mathrm{~kb}$ SphI fragment into pUC118 (pYO-B1) (Fig. 1). A second gene (gene 2) encoding an enzyme that catalyses ring meta-cleavage of 2,3-DHBP was subcloned from pYO1009 as a $3.4 \mathrm{~kb}$ SalI fragment into pUC118 (pYO-B2). Sequence analysis of two clones revealed that gene 1 was $100 \%$ identical to todE $E_{\mathrm{F} 1}$, encoding the toluene dihydroxy dioxygenase of $P$. putida $\mathrm{F} 1$, and gene 2 was $100 \%$ identical to $c m t C_{\mathrm{F} 1}$, encoding the cumate dioxygenase of P. putida F1. A cosmid library containing approximately 5000 clones was tested for meta-cleavage dioxygenase activity as described above. Twenty-one colonies were positive. Cosmid DNA was prepared from each of these clones and genomic DNA was extracted from P. putida CE2010 and $P$. putida F1. Southern hybridization analysis was carried out using todE $E_{\mathrm{CE2010}}$ (encoded by gene 1 ) and $c m t \mathrm{C}_{\mathrm{CE2010}}$ (encoded by gene 2) as probes. pYOS13 contained a $27 \mathrm{~kb}$ fragment and hybridized with both tod $E_{\mathrm{CE2010}}$ and $c m t C_{\mathrm{CE2010}}$. Under stringent conditions, its hybridization pattern with the two probes showed no notable difference compared to that in the case of $P$. putida F1 (Fig. 1). It was confirmed that P. putida CE2010 could utilize toluene, cumate or cymene as sole carbon source. These results indicate that $P$. putida CE2010 possesses the $t o d_{\mathrm{CE2010}}$ operon, the $c m t_{\mathrm{CE2010}}$ operon and the $c y m_{\mathrm{CE2} 2010}$ operon and that the location of the $c m t_{\mathrm{CE} 2010}$ and $t o d_{\mathrm{CE} 2010}$ operons in P. putida CE2010 is the same as that in P. putida F1. 


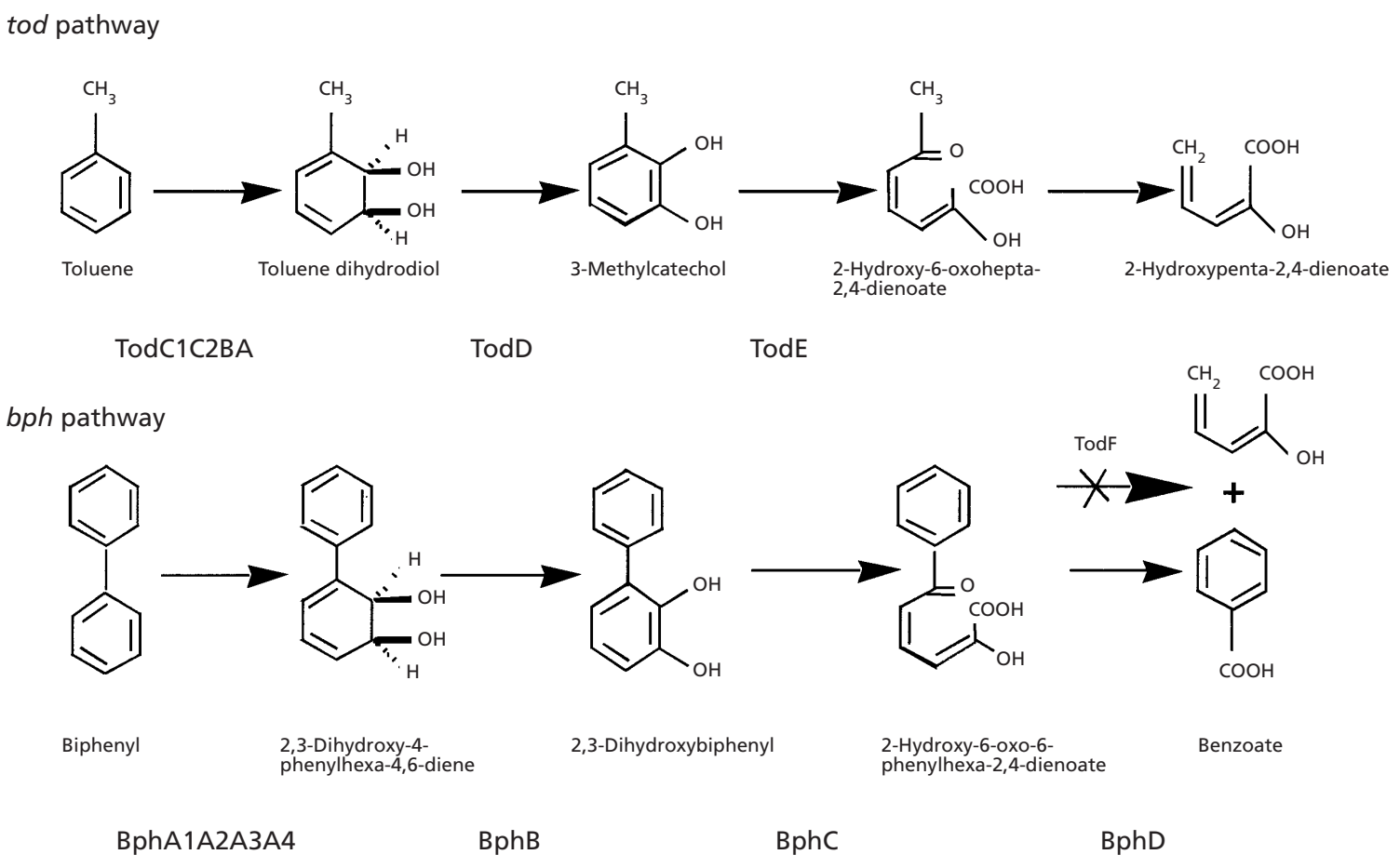

Fig. 2. Metabolic pathways encoded by the tod and bph operons. TodC1C2BA, components of toluene dioxygenase; TodD, cis-toluene dihydrodiol dehydrogenase; TodE, 3-methylcatechol 2,3-dioxygenase; TodF, 2-hydroxy-6oxohepta-2,4-dienoate hydrolase; BphA1A2A3A4, components of biphenyl dioxygenase; BphB, 2,3-dihydroxy-4phenylhexa-4,6-diene dehydrogenase; BphC, 2,3-DHBD; BphD, HPDA hydrolase.

\section{Metabolic pathway encoded by the tod and bph operons}

Toluene-utilizing $P$. putida F1 could not grow on biphenyl, but toluene-grown P. putida F1 cells did convert biphenyl into the meta-cleavage product HPDA (Furukawa et al., 1993). These observations suggested that toluene dioxygenase (TodC1C2BA), toluene dihydrodiol dehydrogenase (TodD) and 3-methylcatechol dioxygenase (TodE) are all active in the conversion of biphenyl to HPDA. However, 2-hydroxy6-oxo-hepta-2,4-dienoic acid (HOHD) hydrolase (TodF) did not act on HPDA (Fig. 2).

The $\operatorname{tod} F_{\mathrm{CE} 2010}$ gene of strain CE2010 was subcloned from pYO-C5 as a $1.6 \mathrm{~kb}$ XhoI-SphI fragment into pUC118 (pYO-C10) and sequence analysis showed that the DNA sequence of the $t o d F_{\mathrm{CE} 2010}$ gene in $P$. putida CE2010 was $100 \%$ identical to that of $\operatorname{todF}_{\mathrm{F} 1}$ in $P$. putida F1. E. coli carrying pYO-C10 expressed no detectable HPDA hydrolysis activity. Thus, it seems that $P$. putida CE2010 possesses an enzyme that hydrolyses HPDA, which is different from $T_{\text {odF }} \mathrm{CE2010}_{\text {, }}$ and that this enzyme enables $P$. putida CE2010 to assimilate HPDA. Cell lysates prepared from $P$. putida CE2010 grown on biphenyl showed HPDA hydrolysis activity [0.019 units $\mathrm{mg}^{-1}$ (1 unit $=1 \mu \mathrm{mol}$ HPDA hydrolysed $\mathrm{min}^{-1}$ ] and also weak HPDA hydrolysis activity $\left(0.002\right.$ units $\left.\mathrm{mg}^{-1}\right)$ when grown on glucose. HPDA hydrolysis activity increased 10-fold when P. putida CE2010 was grown with biphenyl as sole carbon source. However, cell lysates prepared from $P$. putida F1 grown on glucose did not show HPDA hydrolysis activity.

\section{Purification of an enzyme hydrolysing HPDA from P. putida CE2010}

The enzyme which hydrolyses HPDA was purified as described in Methods. The results are summarized in Table 2. The purity of the enzyme obtained was estimated to be $>95 \%$ by SDS-PAGE (not shown). The apparent molecular mass of the purified enzyme, as determined by SDS-PAGE, was $30 \mathrm{kDa}$. Gel-permeation chromatography under non-denaturing conditions on Superose S200HR, calibrated with globular proteins, indicated an apparent molecular mass of $60 \mathrm{kDa}$. This implies a dimeric structure of the enzyme in its native form. The N-terminal amino acid sequence of the purified enzyme was determined to be $\mathrm{NH}_{2}{ }^{-}$ NLSLDLLGATIRFVDTKAFGTIRIA. This sequence information was used to identify the corresponding gene. The sequence identified was identical to that of $\mathrm{CmtE}_{\mathrm{F} 1}$, 2-hydroxy-6-oxo-7-methylocat-2,4-dienoate hydrolase, of P. putida F1 (Eaton, 1996).

\section{The $c m t E_{\mathrm{CE2010}}$ gene is required for growth of strain CE2010 on biphenyl}

To confirm whether $\mathrm{CmtE}_{\mathrm{CE2010}}$ hydrolyses HPDA, the $c m t E_{\mathrm{CE2010}}$ gene was subcloned from pYOS13 as a $2 \cdot 0 \mathrm{~kb}$ XhoI fragment into pUC118, yielding plasmid 
Table 2. Purification of an enzyme which hydrolyses HPDA from P. putida CE2010

\begin{tabular}{|lcccccc|}
\hline Step & $\begin{array}{c}\text { Volume } \\
(\mathbf{m l})\end{array}$ & $\begin{array}{c}\text { Total protein } \\
(\mathbf{m g})\end{array}$ & $\begin{array}{c}\text { Total activity } \\
(\mathbf{u n i t s})^{* *}\end{array}$ & $\begin{array}{c}\text { Recovery } \\
(\%)\end{array}$ & $\begin{array}{c}\text { Specific activity } \\
\left(\mathbf{\text { units }} \mathbf{m g}^{-1}\right)\end{array}$ & $\begin{array}{c}\text { Purification } \\
(-\mathbf{f o l d})\end{array}$ \\
\hline Cell extract & 22 & 860 & $16 \cdot 3$ & 100 & $0 \cdot 019$ & - \\
$\left(\mathrm{NH}_{4}\right)_{2} \mathrm{SO}_{4}$ & 40 & 320 & $10 \cdot 3$ & $64 \cdot 4$ & $0 \cdot 033$ & $1 \cdot 7$ \\
Phenyl Sepharose & 36 & $25 \cdot 3$ & $9 \cdot 7$ & $59 \cdot 5$ & $0 \cdot 441$ & $23 \cdot 3$ \\
MonoQ & 4 & $0 \cdot 5$ & $0 \cdot 3$ & $1 \cdot 8$ & $0 \cdot 593$ \\
\hline
\end{tabular}

$*$ One unit $=1 \mu \mathrm{mol}$ HPDA hydrolysed $\mathrm{min}^{-1}$.

pYO250. Subclone pYO250 expressed detectable HPDA hydrolysis activity $\left(0 \cdot 13\right.$ units $\left.\mathrm{mg}^{-1}\right)$. This result indicates that the $\mathrm{CmtE}_{\mathrm{CE2010}}$ hydrolyses HPDA.

To confirm the involvement of $\mathrm{CmtE}_{\mathrm{CE2010}}$ in biphenyl utilization in $P$. putida CE2010, the $c m t E_{\mathrm{CE2} 2010}$ gene in the chromosome was selectively interrupted by insertion of a $\mathrm{Tc}^{\mathrm{r}}$ gene from $\mathrm{pBR} 322$ into a unique $K p n \mathrm{I}$ site, thus interrupting only $\mathrm{CmtE}_{\mathrm{CE} 2010}$. Chromosomal integration was confirmed for one of the insertional mutants by Southern blot analysis of the $c m t E_{\mathrm{CE} 2010}$ region using a $2.0 \mathrm{~kb}$ XhoI fragment from pYO250 as a probe. $P$. putida CE2010 $\left(\mathrm{cmtE}_{\mathrm{CE2010}}:: \mathrm{Tc}^{\mathrm{r}}\right)$ did not grow on biphenyl; there were no colonies visible even after $7 \mathrm{~d}$ incubation, whereas colonies of $P$. putida CE2010 were visible within $2 \mathrm{~d}$. Also, this mutant could not utilize cumate as sole carbon source. These results indicate that $\mathrm{CmtE}_{\mathrm{CE2010}}$ enables P. putida CE2010 to utilize biphenyl as a carbon source.

\section{Both $c m t E_{\mathrm{CE} 2010}$ and the $\operatorname{tod}_{\mathrm{CE} 2010}$ operon are required for growth with biphenyl}

It was shown that $\mathrm{CmtE}_{\mathrm{CE2010}}$ hydrolyses HPDA and that it contributes to biphenyl utilization in $P$. putida CE2010. It was expected that the $c m t_{\mathrm{CE2010}}$ operon was involved in biphenyl utilization in this strain. The $c m t_{\mathrm{F} 1}$ operon encodes the enzymes required for $p$ cumate metabolism in P. putida F1 (Eaton, 1996). $C m t A a A b A c A d_{\mathrm{F} 1}$ encode the components of the $p$ cumate 2,3-dioxygenase (ferredoxin reductase, the large subunit of the terminal dioxygenase, the small subunit of the terminal dioxygenase and ferredoxin, respectively), $c m t C_{\mathrm{F} 1}$ encodes 2,3-dihydroxy-p-cumate 3,4dioxygenase, $\quad c m t B_{\mathrm{F} 1}$ encodes 2,3-dihydroxy-2,3dihydro- $p$-cumate dehydrogenase and $c m t E_{\mathrm{F} 1}$ encodes 2-hydroxy-6-oxo-7-methylocta-2,4-dienoate hydrolase. These genes show similarity in terms of gene organization as well as size and homology to the corresponding genes for $b p h$ metabolism enzymes. The $c m t_{\mathrm{F} 1}$ operon also encodes $c m t F H G_{\mathrm{F} 1}$ whose products convert isobutyrate to tricarboxylic acid cycle intermediates. The $c m t F H G_{\mathrm{F} 1}$ genes show homology to bphEGF, respectively, which encode enzymes involved in the downstream portion of the biphenyl metabolic pathway. Thus, it might be possible that the $c m t_{\mathrm{CE2010}}$ operon, not the $t o d_{\mathrm{CE} 2010}$ operon, is entirely responsible for the ability of P. putida CE2010 to utilize biphenyl. To test whether the $\operatorname{tod}_{\mathrm{CE} 2010}$ operon in P. putida CE2010 is required for biphenyl degradation, the tod $_{\mathrm{CE2010}}$ operon was disrupted. When a $\mathrm{Km}^{\mathrm{r}}$ gene and an $r r n B$ terminator gene from E. coli were inserted into the $S p h \mathrm{I}$ site of the todC1 $1_{\mathrm{CE} 2010}$ gene in P. putida CE2010 as described in Methods, the insertion mutant could not grow on biphenyl or toluene as sole carbon source. Chromosomal integration was confirmed by Southern blot analysis of the todC1 $1_{\mathrm{CE} 2010}$ region using a $2.0 \mathrm{~kb}$ fragment (containing the todC1 $1_{\mathrm{CE} 2010}$ gene) from pYO$\mathrm{C} 5$ as probe (not shown). It seems likely that all or part of both the $\operatorname{tod}_{\mathrm{CE} 2010}$ operon and the $c m t_{\mathrm{CE} 2010}$ operon are required for degradation of biphenyl by $P$. putida CE2010. It has been reported that the failure of $P$. putida F1 to grow on biphenyl is simply due to lack of HPDA hydrolase activity in $P$. putida F1 grown on toluene (Furukawa et al., 1993). Introduction of $b p h D$ (the KF707 HPDA hydrolase gene) into $P$. putida F1 permitted growth on biphenyl. To confirm whether only the $c m t E_{\mathrm{CE2010}}$ gene in addition to the $\operatorname{tod}_{\mathrm{CE2010}}$ operon is required for biphenyl degradation in P. putida CE2010, the $c m t_{\mathrm{CE} 2010}$ operon in P. putida CE2010 was disrupted and then an intact $c m t E_{\mathrm{CE2010}}$ gene was introduced. When a $\mathrm{Km}^{\mathrm{r}}$ gene and an $\mathrm{rrnB}$ terminator gene from E. coli were inserted into the EcoRV site of the cmtAa $a_{\mathrm{CE} 2010}$ gene in P. putida CE2010, the loss of biphenyl utility was observed. However, when pMTC101, $c m t E_{\mathrm{CE} 2010}$ in pMTC67EH, was introduced into this insertion mutant, the ability to utilize biphenyl as sole carbon source for growth was restored with IPTG as the inducer. When P. putida F1 was transformed with pMTC101, it could utilize biphenyl as sole carbon source with IPTG as the inducer (data not shown). These results indicate that the $c m t E_{\mathrm{CE2010}}$ gene and the tod $_{\mathrm{CE2010}}$ operon are required for biphenyl utilization in the case of $P$. putida CE2010.

\section{Sequence analysis of the $\mathrm{cmt}_{\mathrm{CE2} 210}$ operon in P. putida CE2010}

The $c m t E_{\mathrm{CE2010}}$ gene in P. putida CE2010 is expressed in the presence of biphenyl, whereas that in P. putida F1 is not. Chromosomal DNA was isolated from $P$. putida CE2010 and from P. putida F1, then digested with various kinds of restriction enzymes and subjected to Southern hybridization with the $c m t E_{\mathrm{CE2010}}$ gene as a 


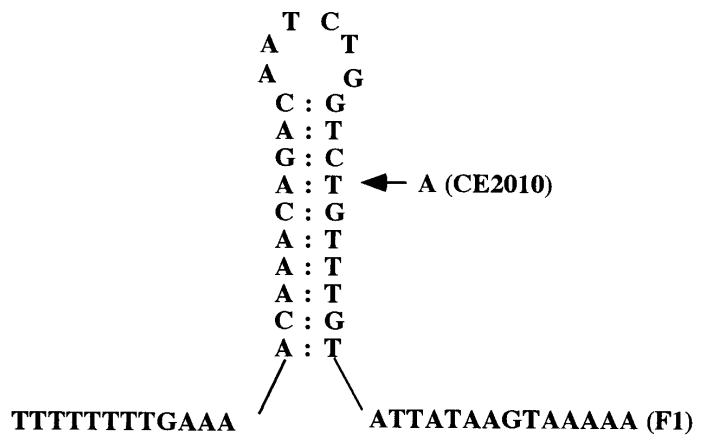

Fig. 3. Sequence of the $\mathrm{cmt}$ promoter-operator region and its potential hairpin structure. The arrow indicates the position of the single base difference between the sequences of $P$. putida CE2010 and P. putida F1. The hairpin is between -30 and -10 in $P$. putida $\mathrm{F} 1$ and has a free energy value of $-13.1 \mathrm{kcal}$. The change to $T$ at -7 (indicated by the arrow) in $P$. putida CE2010 would reduce this to $-8.8 \mathrm{kcal}$. The sequence is numbered according to Eaton (1997).

probe. The hybridization patterns showed no apparent difference between P. putida CE2010 and P. putida F1. Using pYOS13, we analysed the entire sequence of the $c m t_{\mathrm{CE2010}}$ operon from 11231 to 24937 (numbering according to Eaton, 1997) and a part of the $\operatorname{tod}_{\mathrm{CE2010}}$ operon from 1 to 3545 (numbering according to Wang et al., 1995) in P. putida CE2010. A single base difference was found upstream of the $c m t_{\mathrm{CE2010}}$ operon (Fig. 3). In $P$. putida F1, this region is the putative operatorpromoter region of the $c m t_{\mathrm{F} 1}$ operon and is located between the putative $-35,-10\left(\sigma^{70}\right)$ promoter (Harley \& Reynolds, 1987) and the beginning of $\mathrm{cmtAa} a_{\mathrm{F} 1}$ (Eaton, 1997). It was proposed that this is a recognition site (operator) for CymR, the putative repressor protein regulating expression of the $c m t_{\mathrm{F} 1}$ and $c y m_{\mathrm{F} 1}$ operons, and forms a hairpin structure (Eaton, 1997). In the case of $P$. putida F1, the hairpin is between -87 and -62 , where -1 is the base preceding the A of the ATG initiation codon of $c m t A a_{\mathrm{F} 1}$, and it has a free energy value of $-13 \cdot 1 \mathrm{kcal}(1 \mathrm{cal}=4 \cdot 184 \mathrm{~J})$. In $P$. putida CE2010 the single base difference was located at the base of a putative hairpin structure (Fig. 3). In the case of $P$. putida CE2010 the value would be reduced to $-8 \cdot 8 \mathrm{kcal}$. This single base difference seems to generate instability in the hairpin structure and this is likely to affect the interaction with $\mathrm{CymR}_{\mathrm{CE2010}}$. We also analysed the sequence of $c y m R_{\mathrm{CE2010}}$ in P. putida CE2010 and there was no difference compared to $c y m R_{\mathrm{F} 1}$ in P. putida F1.

\section{Assay of the binding of CymR to the $\mathrm{cmt}$ promoter region}

To compare the binding of CymR to the promoter region of the cmt operon of $P$. putida CE2010 and that of $P$. putida F1, a gel shift assay was performed using purified CymR and two synthetic DNA fragments. CymR was prepared as described in Methods. dsDNA fragments $(100 \mathrm{bp})$ corresponding to the $\mathrm{cmt}$ promoter region of $P$. putida CE2010 (CEPro) and that of $P$. putida (a)

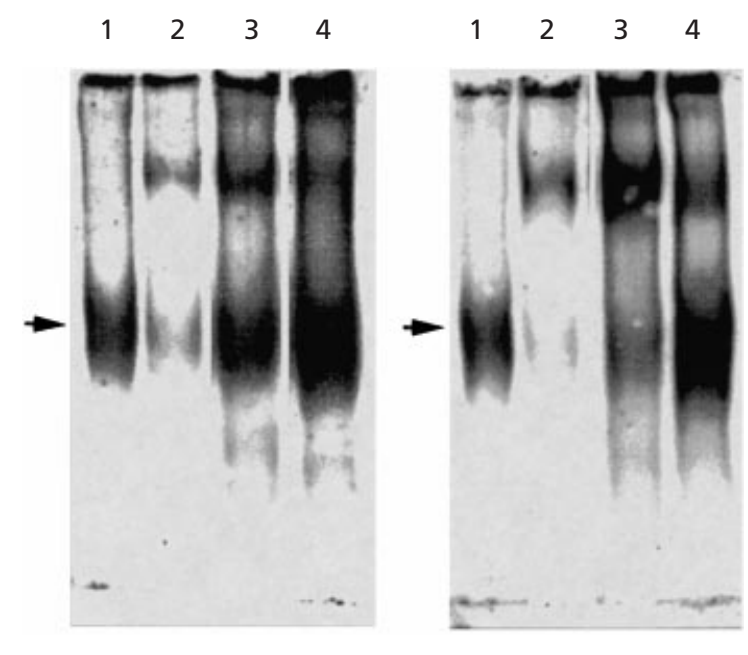

Fig. 4. Comparison of the binding of $C y m R$ to the $\mathrm{cmt}$ promoter region of $P$. putida F1 (F1Pro) and $P$. putida CE2010 (CEPro). A gel shift assay was performed as described in Methods. Purified CymR was incubated with CEPro (a) or F1Pro (b). Lanes: 1, digoxigenin-labelled CEPro (a) or F1Pro (b) (40 fmol) alone; 2,3 , purified CymR $(1 \mu \mathrm{g})$ incubated with 40 (lane 2) or $200 \mathrm{fmol}$ (lane 3) digoxigenin-labelled CEPro (a) or F1Pro (b); 4, purified CymR $(1 \mu \mathrm{g})$ was incubated with $200 \mathrm{fmol}$ digoxigenin-labelled CEPro (a) or F1Pro (b) and 2 pmol unlabelled CEPro (a) or F1Pro (b).

F1 (F1Pro) were synthesized and labelled with digoxigenin at the $3^{\prime}$ terminus. A mixture of these DNA fragments was used in the binding studies, incubated with the purified CymR.

A specific DNA-CymR complex was observed when labelled F1Pro was incubated with CymR (Fig. 4b). The retarded band disappeared upon addition of a 10 -fold molar excess of unlabelled F1Pro. These results indicate that CymR binds to this region specifically. In contrast, a weak DNA-CymR complex band was observed when labelled CEPro was incubated with CymR (Fig. 4a). The single base difference in the $c m t_{\mathrm{CE} 2010}$ promoter region of $P$. putida CE2010, compared to that of $P$. putida F1, resulted in a decreased amount of retarded DNA band. These results indicate that CymR binds less strongly to the $c m t_{\mathrm{CE2010}}$ promoter region of $P$. putida CE2010 than to the $c m t_{\mathrm{F} 1}$ promoter region of $P$. putida F1. Thus, the observed single base difference affects the binding of the CymR regulator to this region. It is expected that the regulation of the $c m t_{\mathrm{CE2010}}$ operon in $P$. putida CE2010 is different from that in $P$. putida F1.

\section{Exchanging the $\mathrm{cmt}$ promoter region between $P$. putida CE2010 and P. putida F1}

To further elucidate the influence of the $\mathrm{cmt}$ promoteroperator region on biphenyl utilization in vivo, the $P$. putida CE2010 $\mathrm{cmt}_{\mathrm{CE2010}}$ promoter region was replaced with the $P$. putida F1-type $c m t_{\mathrm{F} 1}$ promoter region and vice versa. The recombinant $P$. putida CE2010 could not 
Table 3. Exchange of $\mathrm{cmt}$ promoter-operator region between $P$. putida CE2010 and P. putida F1

The mutants were streaked on $\mathrm{C}$ medium plates containing $\mathrm{Tc}$ with the carbon sources indicated. The plates were incubated for $7 \mathrm{~d}$ at $30^{\circ} \mathrm{C}$.

\begin{tabular}{|lcccccc|}
\hline \multirow{2}{*}{ C source } & \multicolumn{2}{c}{$\boldsymbol{P}$. putida CE2010 } & & \multicolumn{2}{c|}{$\boldsymbol{P}$. putida F1 } \\
\cline { 2 - 3 } \cline { 5 - 6 } & CE pro & F1 pro & & CE pro & F1 pro \\
\cline { 5 - 6 } & + & + & & + & + \\
Toluene & + & - & & - & - \\
Biphenyl & + & + & & + & + \\
Cumate & + & + & & + & + \\
Cymene & + & + & & + & \\
\hline
\end{tabular}

utilize biphenyl as sole carbon source (Table 3). This result supports the view that the $c m t_{\mathrm{CE2010}}$ promoter region in $P$. putida CE2010 is essential for its ability to utilize biphenyl. On the other hand, when the P. putida CE2010-type $\mathrm{cmt}_{\mathrm{CE2010}}$ promoter region was introduced into $P$. putida F1, the recombinant $P$. putida F1 could not grow on biphenyl as sole carbon source as determined after $10 \mathrm{~d}$ incubation.

\section{DISCUSSION}

Biphenyl degrader P. putida CE2010 is an organicsolvent-tolerant bacterium capable of growth on toluene in LB medium and capable of degrading biphenyl in a two-phase system. P. putida CE2010 was found to have both the $t o d_{\mathrm{CE2010}}$ operon and the $c m t_{\mathrm{CE2010}}$ operon and to utilize toluene, cumate or cymene as sole carbon source. The location of the $c m t_{\mathrm{CE2010}}$ and the $t o d_{\mathrm{CE} 2010}$ operons is the same as that in P. putida F1. P. putida CE2010 is very similar to $P$. putida F1 in this aspect.

Results obtained through purification of the HPDAhydrolysing protein of P. putida CE2010 and determination of its $\mathrm{N}$-terminal sequence indicate that $\mathrm{CmtE}_{\mathrm{CE2010}}$ is involved in biphenyl utilization in $P$. putida CE2010. $\mathrm{CmtE}_{\mathrm{F} 1}$ encodes 2-hydroxy-6-oxo-7methylocta-2,4-dienoate hydrolase (Eaton, 1996). The degree of amino acid sequence homology between $\mathrm{CmtE}_{\mathrm{CE2010}}$ and other BphD-like hydrolases is relatively low. CmtE showed 27-33\% identity with $\mathrm{BphD}_{\mathrm{KKS102}}$ (Kimbara et al., 1989), $\mathrm{BphD}_{\mathrm{LB} 400}$ (Hofer et al., 1993), $\mathrm{BphD}_{\mathrm{KF} 715}$ (Hayase et al., 1990), $\mathrm{BphD}_{\mathrm{B} 356}$ (Ahmad et al., 1995), $\mathrm{BphD}_{\mathrm{RHA} 1}$ (Masai et al., 1997), $\mathrm{BphD}_{\mathrm{M} 5}$ (Lau et al., 1996), TodF $\mathrm{F}_{1}$ (Menn et al., 1991) and $\mathrm{XylF}_{\mathrm{mt2}}$ (Horn et al., 1991). The amino acid sequence identities between KKS102, LB400, KF715 and B-356 BphDs and those between XylF and TodF of Pseudomonas strains are much higher (69 and 53\%, respectively). The sequences of $\mathrm{BphD}_{\mathrm{LB} 400}$ and $\mathrm{BphD}_{\mathrm{M} 5}$ are only $42 \%$ identical and that of $\mathrm{BphD}_{\mathrm{RHA} 1}$ is only $30 \%$ identical to both of these. From the viewpoint of substrate specificity, some BphD proteins hydrolyse both HPDA and HOHD and show relatively broad substrate specificities. $\mathrm{BphD}_{\mathrm{LB} 400}$ hydrolyses relatively well analogues of HPDA that contain at least a two-carbon group at C-6 (Seah et al., 1998). The specificities of the enzyme for HPDA and 2-hydroxy-6-oxo-7-methylocta2,4-dienoate differ only by a factor of five. So it may not be surprising that $\mathrm{CmtE}_{\mathrm{CE2010}}$ can hydrolyse HPDA despite having relatively low homology with BphD.

The phenotype of the $\mathrm{CmtE}_{\mathrm{CE2010}}$ disruption mutant and that of the $\operatorname{tod}_{\mathrm{CE2010}}$ operon disruption mutant indicate that $P$. putida CE2010 degrades biphenyl by means of a mosaic of pathways consisting of enzymes encoded by the $\operatorname{tod}_{\mathrm{CE2010}}$ and $c m t_{\mathrm{CE2010}}$ operons. The $\mathrm{cmt}_{\mathrm{CE2010}}$-operon-disrupted mutant could not utilize biphenyl, but when $c m t E_{\mathrm{CE2010}}$ was introduced into the mutant, it was able to grow on biphenyl. These results indicate that $c m t E_{\mathrm{CE} 2010}$ and the $\operatorname{tod}_{\mathrm{CE} 2010}$ operon are responsible for degradation of biphenyl in the case of $P$. putida CE2010. In the case of $P$. putida F1, the range of compounds that can be degraded by the $\operatorname{tod}_{\mathrm{F} 1}$ pathway is limited by $\mathrm{TodF}_{\mathrm{F} 1}$, which shows narrow substrate specificity. In P. putida CE2010, the recruitment of only one enzyme, $\mathrm{CmtE}_{\mathrm{CE2010}}$, which P. putida CE2010 has, is sufficient to expand the substrate specificity of the tod $_{\mathrm{CE2010}}$ pathway to include biphenyl.

Sequence analysis of the $c m t_{\mathrm{CE} 2010}$ operon in P. putida CE2010 showed that there was a single base difference in the region upstream of the $c m t_{\mathrm{CE2010}}$ operon as compared to that in $P$. putida F1. In P. putida F1, this region was expected to be the CymR recognition site (Eaton, 1997). Eaton demonstrated that CymR is a repressor protein regulating expression of the $c y m_{\mathrm{F} 1}$ and $c m t_{\mathrm{F} 1}$ operons. In P. putida CE2010, the single base difference was located within a predicted hairpin structure in the promoter region and was expected to destabilize the structure.

Results of the gel shift assay indicate that CymR binds less strongly to the $c m t_{\mathrm{CE2010}}$ promoter region derived from P. putida CE2010 than to the corresponding region from $P$. putida F1. These results indicate that the single base difference in the $c m t_{\mathrm{CE2010}}$ promoter region affects the binding of CymR to this region. It seems likely that, in P. putida CE2010, due to the single base difference in the promoter region, CymR does not efficiently repress the $c m t_{\mathrm{CE2010}}$ promoter, resulting in expression of the $\mathrm{cmt}_{\mathrm{CE2010}}$ operon. These results explain the constitutive expression of $\mathrm{CmtE}_{\mathrm{CE} 2010}$ at a comparatively low level in $P$. putida CE2010 cultured with glucose as carbon source.

When the $c m t_{\mathrm{CE2010}}$ promoter in P. putida CE2010 was replaced with the $P$. putida F1-type $c m t_{\mathrm{F} 1}$ promoter, the recombinant $P$. putida CE2010 could not utilize biphenyl as sole carbon source. This result supports the view that the single base difference in the $c m t_{\mathrm{CE2010}}$ promoter region of $P$. putida CE2010 is essential for its ability to degrade biphenyl. On the other hand, when the $\mathrm{cmt}_{\mathrm{CE2010}}$ promoter from P. putida CE2010 was introduced into $P$. putida $\mathrm{F} 1$, the recombinant $P$. putida $\mathrm{F} 1$ could not grow on biphenyl as sole carbon source as determined after $7 \mathrm{~d}$. However, after 2 weeks, several colonies appeared, whereas the wild-type P. putida F1 
could not grow on biphenyl even when incubated for more than 2 weeks (data not shown). These findings suggest that the single base difference is necessary, but not sufficient for the expression of the $\mathrm{cmt}$ operon in $P$. putida F1 with biphenyl. It is suspected that the introduction of the $c m t_{\mathrm{CE} 2010}$ promoter in P. putida F1 cannot cause the expression of $\mathrm{CmtE}$ in the modified F1 strain to the same level as in strain CE2010. Other factors in addition to the single base difference in the $c m t_{\mathrm{CE2010}}$ promoter region might be required for $P$. putida F1 to utilize biphenyl. This may explain why the wild-type $P$. putida F1 rarely turns into a biphenyl utilizer spontaneously. P. putida CE2010 is very similar to $P$. putida F1, but not identical. It is also suspected that the regulation of $c m t$ operon expression in P. putida F1 is not always identical to that in P. putida CE2010.

Expression of the tod operon is regulated by the TodST system, a two-component system (Lau et al., 1997). The todS gene encodes a sensory hybrid kinase and the todT gene product is an activator of tod structural genes. The toluene utilizer $P$. putida F1 converted biphenyl into the yellow meta-cleavage product HPDA through the action of the components of the tod pathway (Furukawa et al., 1993). Although these authors did not mention the regulation of the expression of the tod operon in the presence of biphenyl, this indicates that in P. putida F1 biphenyl was transported into the cell and the Tod enzymes were expressed in the presence of biphenyl. It is possible that production of the meta-cleavage product is due to low constitutive expression of Tod enzymes, or the induced expression of Tod enzymes by biphenyl or an intermediate of the pathway in P. putida CE2010 as well as P. putida F1.

P. putida CE2010 showed weak HPDA hydrolysis activity $\left(0.002\right.$ units $\left.\mathrm{mg}^{-1}\right)$ when grown on glucose. It is expected that in $P$. putida CE2010, due to the single base difference in the promoter region, the expression of $\mathrm{cmt}$ is caused by ineffective repression by CymR, leading to low, constitutive expression.

When P. putida CE2010 was grown with biphenyl as sole carbon source, HPDA hydrolysis activity increased 10-fold. This indicates that in P. putida CE2010 the expression of the $c m t$ operon is induced in the presence of biphenyl. In P. putida F1, CymR is a repressor protein regulating expression of the cym and cmt operons. CymR is $100 \%$ identical in CE2010 and F1. In P. putida $\mathrm{F} 1, p$-cumate acts as an effector of both the cym and $\mathrm{cmt}$ operons, whereas $p$-cymene is not an effector. Since the structures of $p$-cumate and biphenyl are quite different, biphenyl is not expected to be an effector of the cmt operon in P. putida CE2010. An intermediate of the pathway consisting of $\mathrm{cm} t$ and the tod operon might be an effector in P. putida CE2010. There is a possibility that in P. putida CE2010 regulatory proteins other than CymR are also involved in regulating expression of the $c m t_{\mathrm{CE2010}}$ operon in the presence of biphenyl. In $P$. putida F1, such mechanisms might not exist or may not be modulated by biphenyl or the intermediates or the products.
Our study serves to demonstrate how, with a slight change in a regulatory region, two distinct degradation pathways with distinct substrate spectra can expand substrate specificity via a mosaic of the pathways. It is also expected that not only the hydrolysis step, but also an earlier step, the meta-cleavage or later steps in the degradation pathway may expand substrate specificity in P. putida CE2010 as a result of the mosaic of pathways. Our results suggest that catabolic enzymes and catabolic gene regulators exhibit considerable evolutionary potential. Bacteria could acquire broad substrate specificities with a hybrid pathway consisting of the products of two distinct operons.

\section{ACKNOWLEDGEMENTS}

We are very grateful to $\mathrm{K}$. Horikoshi for encouraging us during this study. This work was partially supported by a grant for the Eco Molecular Sciences Research Program from RIKEN.

\section{REFERENCES}

Ahmad, D., Fraser, J., Sylvestre, M., Larose, A., Khan, A., Bergeron, J., Juteau, J. M. \& Sondossi, M. (1995). Sequence of the $b p h D$ gene encoding 2-hydroxy-6-oxo-(phenyl/chlorophenyl)hexa-2,4-dienoic acid (HOP/cPDA) hydrolase involved in the biphenyl/polychlorinated biphenyl degradation pathway in Comamonas testosteroni: evidence suggesting involvement of Ser112 in catalytic activity. Gene 156, 69-74.

Anderson, M. L. \& Young, B.D. (1985). Quantitative filter hybridization. In Nucleic Acid Hybridization, pp. 73-110. Edited by B. D. Hames \& S. J. Higgins. Oxford: IRL Press.

Bradford, M. M. (1976). A rapid and sensitive method for the quantitation of microgram quantities of protein utilizing the principle of protein-dye binding. Anal Biochem 72, 248-254.

Catelani, D., Colombi, A., Sorlini, C. \& Treccani, V. (1973). 2Hydroxy-6-oxo-6-phenylhexa-2,4-dienoate: the meta-cleavage product from 2,3-dihydroxybiphenyl by Pseudomonas putida. Biochem J 134, 1063-1066.

Eaton, R. W. (1996). p-Cumate catabolic pathway in Pseudomonas putida F1: Cloning and characterization of DNA carrying the cmt operon. J Bacteriol 178, 1351-1362.

Eaton, R. W. (1997). p-Cymene catabolic pathway in Pseudomonas putida F1: Cloning and characterization of DNA encoding conversion of $p$-cymene to $p$-cumate. J Bacteriol 179, 3171-3180.

Fürste, J. P., Pansegrau, W., Frank, R., Blocker, H., Scholz, P., Bagdasarian, M. \& Lnaka, E. (1986). Molecular cloning of the plasmid RP4 primase region in a multi-host-range tacP expression vector. Gene 48, 119-131.

Furukawa, K., Hirose, J., Suyama, A., Zaiki, T. \& Hayashida, S. (1993). Gene components responsible for discrete substrate specificity in the metabolism of biphenyl ( $b p h$ operon) and toluene (tod operon). J Bacteriol 175, 5224-5232.

Gibson, D. T., Koch, J.R. \& Kallio, R. E. (1968). Oxidative degradation of aromatic hydrocarbons by microorganisms. I. Enzymatic formation of catechol from benzene. Biochem 7, 2653-2662.

Harayama, S. \& Rekik, S. (1990). The meta cleavage operon of TOL degradative plasmid pWWO comprises 13 genes. Mol Gen Genet 221, 113-120.

Harayama, S., Rekik, M., Bairoch, A., Neidle, E. L. \& Ornston, L. N. (1991). Potential DNA slippage structures acquired during 
evolutionary divergence of Acinetobacter calcoaceticus chromosomal benABC and Pseudomonas putida TOL pWWO plasmid $x y l X Y Z$, genes encoding benzoate dioxygenases. J Bacteriol 173, 7540-7548.

Harley, C. B. \& Reynolds, R. P. (1987). Analysis of E. coli promoter sequences. Nucleic Acids Res 15, 2347-2351.

Hayase, N., Taira, K. \& Furukawa, K. (1990). Pseudomonas putida KF715 bphABCD operon encoding biphenyl and polychlorinated biphenyl degradation: cloning, analysis, and expression in soil bacteria. J Bacteriol 172, 1160-1164.

Hofer, B., Eltis, L. D., Dowling, D. N. \& Timmis, K. N. (1993). Genetic analysis of a Pseudomonas locus encoding a pathway for biphenyl/polychlorinated biphenyl degradation. Gene. 130, 47-55.

Horn, J. M., Harayama, S. \& Timmis, K. N. (1991). DNA sequence determination of the TOL plasmid ( $\mathrm{pWW}$ ) $x y l G F J$ genes of Pseudomonas putida: implication for the evolution of aromatic catabolism. Mol Microbiol 5, 2459-2474.

Irie, S., Doi, S., Yorifuji, T., Takagi, M. \& Yano, K. (1987). Nucleotide sequencing and characterization of the genes encoding benzene oxidation enzymes of Pseudomonas putida. J Bacteriol 169, 5174-5179.

Kimbara, K., Hashimoto, T., Fukuda, M., Koana, T., Takagi, M., Oishi, M. \& Yano, K. (1989). Cloning and sequencing of two tandem genes involved in degradation of 2,3-dihydroxybiphenyl to benzoic acid in the polychlorinated biphenyl-degrading soil bacterium Pseudomonas sp. strain KKS102. J Bacteriol 171, 2740-2747.

Lau, P. C. K., Bergeron, H., Labbe, D., Wang, Y., Brousseau, R. \& Gibson, D. T. (1994). Sequence and expression of the todGIH gene involved in the last three steps of toluene degradation by Pseudomonas putida F1. Gene 146, 7-13.

Lau, P. C. K., Garnon, J., Labbe, D. \& Wang, Y. (1996). Location and sequence analysis of a 2-hydroxy-6-oxo-6-phenylhexa-2,4dienoate hydrolase-encoding gene $(b p d F)$ of the biphenyl/ polychlorinated biphenyl degradation pathway in Rhodococcus sp. M5. Gene 171, 53-57.

Lau, P. C. K., Wang, Y., Patel, A., Labbe, D., Bergeron, H., Brousseau, R., Konishi, Y. \& Rauslings, M. (1997). A bacterial basic region leucine zipper histidine kinase regulating toluene degradation. Proc Natl Acad Sci U S A 94, 1453-1458.

Lorenzo, V. D. \& Perez-Martin, J. (1996). Regulatory noise in prokaryotic promoters: how bacteria learn to respond to novel environment signals. Mol Microbiol 19, 1177-1184.

Maeda, M., Chung, S.-Y., Song, E. \& Kudo, T. (1995). Multiple genes encoding 2,3-dihydroxybiphenyl 1,2-dioxygenase in the Gram-positive polychlorinated biphenyl-degrading bacterium Rhodococcus erythropolis TA421, isolated from a termite ecosystem. Appl Environ Microbiol 61, 549-555.

Masai, E., Sugiyama, K., Iwashita, N., Shimizu, S., Hauschild, J. E., Hatta, T., Kimbara, K., Yano, K. \& Fukuda, M. (1997). The $b p h D E F$ meta-cleavage pathway genes involved in biphenyl/ polychlorinated biphenyl degradation are located on a linear plasmid and separated from the initial $b p h A C B$ genes in Rhodococcus sp. strain RHA1. Gene 187, 141-149.

Meer, J. R. V. D., Vos, W. M. D., Harayama, S. \& Zehnder, A. J. B. (1992). Molecular mechanisms of genetic adaptation to xenobiotic compounds. Microbiol Rev 56, 677-694.

Menn, F. M., Zylstra, G. J. \& Gibson, D. T. (1991). Location and sequence of the todF gene encoding 2-hydroxy-6-oxohepta-2,4dienoate hydrolase in Pseudomonas putida F1. Gene 104, 91-94.

Nagata, Y., Imai, R., Sakai, A., Fukuda, M., Yano, K. \& Takagi, M. (1993). Isolation and characterization of Tn-induced mutants of Pseudomonas paucimobilis UT26 defective in r-hexachlorocyclohexane dehydrochlorinase (LinA). Biosci Biotechnol Biochem 57, 703-709.

Ohta, Y., Maeda, M., Kudo, T. \& Horikoshi, K. (1996). Isolation and characterization of solvent-tolerant bacteria which can degrade biphenyl/polychlorinated biphenyls. J Gen Appl Microbiol 42, 349-354.

Sambrook, J., Fritsch, E. F. \& Maniatis, T. (1989). Molecular Cloning: a Laboratory Manual, 2nd edn. Cold Spring Harbor, NY: Cold Spring Harbor Laboratory.

Seah, S. Y. K., Terracina, G., Bolin, J. T., Riebel, P., Snieckus, V. \& Eltis, L. D. (1998). Purification and preliminary characterization of a serine hydrolase involved in the microbial degradation of polychlorinated biphenyls. J Biol Chem 273, 22943-22949.

Southern, E. M. (1975). Detection of specific sequences among DNA fragments separated by gel electrophoresis. J Mol Biol 98, 503-517.

Wang, Y., Rawlings, M., Gibson, D. T., Labbe, D., Bergeron, H., Brousseau, R. \& Lau, P. C. K. (1995). Identification of a membrane protein and a truncated lysR-type regulator associated with the toluene degradation pathway in Pseudomonas putida F1. Mol Gen Genet 246, 570-579.

Wilson, K. (1990). Preparation of genomic DNA from bacteria. In Current Protocols in Molecular Biology, pp. 2.4.1-2.4.5. Edited by F. M. Ausubel, R. Brent, R. E. Kingston, D. D. Moore, J. G. Seidman, H. A. Smith \& K. Struhl. New York: Greene Publishing Association and Wiley.

Zylstra, G. J. \& Gibson, D. T. (1989). Toluene degradation by Pseudomonas putida F1: nucleotide sequence of the todC1C2BADE genes and their expression in Escherichia coli. J Biol Chem 264, 14940-14946.

Zylstra, G. J., McCombie, W. R., Gibson, D. T. \& Finette, B. A. (1988). Toluene degradation by Pseudomonas putida F1: genetic organization of the tod operon. Appl Environ Microbiol 54, 1498-1503.

Received 13 June 2000; revised 21 September 2000; accepted 4 October 2000. 